\title{
ALTERNATIF SITE PLAN UNTUK MENINGKATKAN KELAYAKAN PROYEK PEMBANGUNAN PERUMAHAN X DI KOTA BATU
}

\author{
Sitti Safiatus Riskijah ${ }^{1}$, Susapto $^{2}$, Suselo Utoyo ${ }^{3}$ \\ 1,2,3 Jurusan Teknik Sipil Politeknik Negeri Malang \\ ${ }^{1}$ ririssafiatus@gmail.com, ${ }^{2}$ otpasus@yahoo.com, ${ }^{3}$ sslutoyo@gmail.com \\ (Artikel diterima: Februari 2020, direvisi: April 2020, diterima untuk terbit: Juli 2020)
}

\begin{abstract}
Abstrak - Proyek Pembangunan Perumahan X yang dibangun diatas lahan seluas 267.303,9 m2 memerlukan perencanaan site plan yang baik dan memenuhi peraturan yang berlaku untuk meningkatkan keuntungan perusahaan. Investasi terhadap perumahan memerlukan biaya yang banyak dan waktu yang lama, oleh karena itu diperlukan analisis kelayakan finansial guna mengetahui apakah investasi pembangunan Perumahan X ini layak atau tidak. Penelitian ini bertujuan untuk menganalisis kondisi site plan eksisting, merencanakan 2 alternatif site plan, mengetahui kelayakan finansial dari 3 site plan yang ditinjau, dan memilih site plan yang terbaik secara finansial.Data yang diperlukan adalah site plan kondisi existing. basic design rumah, Analisa Harga Satuan Pekerjaan, Harga Satuan Dasar Kota Batu tahun 2017, biaya lahan, dan biaya perijinan. Analisis site plan eksisting berdasarkan PERMENPERA No. 11 tahun 2008, PERDA Kota Batu No. 7 tahun 2011, dan PERWALI Kota Batu No. 43 tahun 2017. Analisis kelayakan finansial menggunakan parameter Payback Period (PP), Net Present Value (NPV), Benefit Cost Ratio (BCR), dan Internal Rate of Return (IRR).Hasil penelitian menunjukkan bahwa site plan A, B, dan C sudah cukup memenuhi persyaratan yang berlaku. Kelayakan finansial dengan konsep site plan A, B, dan C sudah memenuhi kriteria kelayakan dengan parameter PP < periode investasi dengan nilai masing-masing sebesar 5,37 tahun, 5,22 tahun, dan 5,42 tahun, NPV $>0$ dengan nilai masing-masing sebesar Rp 58.614.912.810, Rp 77.882.006.896, dan Rp 52.343.746.589, dan $\mathrm{BCR}>1$ dengan nilai masing-masing sebesar 1,058, 1,075, dan 1,052, sedangankan dengan parameter IRR hanya site plan B yang layak yaitu dengan nilai masing-masing sebesar 27,004\%, 32,801\% > MARR (30\%), dan 24,322\%. Ratio). Dengan demikian Site Plan B merupkan site plan yang terbaik secara finansial
\end{abstract}

Kata kunci: perumahan, site plan, kelayakan finansial.

\section{Pendahuluan}

Proyek pembangunan Perumahan X di Kota Batu memerlukan suatu perancangan. Dari perancangan tersebut dihasilkan site plan yang seharusnya secara teknis memenuhi ketentuan PERMENPERA No. 11 tahun 2008 tentang Pedoman Keserasian Kawasan Perumahan dan Pemukiman yang mengatur pelaksanaan pemba-ngunan kawasan perumahan.

Kegiatan investasi pada proyek pembangun-an merupakan kegiatan penting yang berdampak secara finansial terhadap kelanjutan suatu usaha. Analisis secara sistematis dan rasional dibutuh-kan sebelum proyek pembangunan dilaksanakan. Hal utama dari analisis tersebut harus mampu memutuskan apakah investasi tersebut mampu memberi manfaat secara finansial kepada per-usahaan dan apakah investasi tersebut meru-pakan pilihan optimal dari segala kemungkinan yang ada. Untuk itu diperlukan analisis finansial untuk menentukan kelayakan pembangunan proyek. Menurut Giatman (2011), metode yang umum digunakan dalam mengevaluasi kelayakan finansial, yaitu: Metode Net Present Value (NPV), Metode Internal Rate of Return (IRR), Metode Benefit Cost Ratio (BCR), dan Metode Payback Period (PP).

Alternatif penyusunan site plan perumahan perlu juga ditawarkan dalam melakukan analisis kelayakan finansial untuk mengetahui site plan Perumahan yang terbaik, tujuannya adalah menentukan site plan yang lebih menguntungkan untuk direalisasikan. Oleh karena itu perlu dicoba untuk mengkaji alternatif site plan untuk meningkatkan kelayakan finansial proyek pembangunan perumahan X di Kota Batu.

Penelitian ini bertujuan untuk melakukan analisis site plan kondisi eksisiting dan merenca-nakan alternative site plan Perumahan X di Kota Batu yang sesuai ketentuan yang berlaku, mengetahui kelayakan finansialnya dengan site plan kondisi eksisting (A) dan allternative site plan ( $B$ dan $C$ ), dan menentukan site plan yang lebih baik dari site plan yang ditinjau dalam penelitian ini berdasarkan nilai parameter kelayakan finansial.

\section{Tinjauan Pustaka}

Pembangunan suatu perumahan harus direncana-kan berdasarkan kebijakan maupun peraturan yang berlaku. Pada UU RI No. 1 tahun 2011, perencanaan dan perancangan rumah dilakukan untuk menciptakan rumah layak huni, mendukung upaya pemenuhan kebutuhan rumah oleh masyarakat dan pemerintah, dan meningkatkan tata bangunan dan lingkungan yang terstruktur.

Berdasarkan PERMENPERA RI No. 38/PRT/ M/2015, yang dimaksud dengan Site plan adalah rencana tapak yang merupakan gambar 2 dimensi yang menunjukkan rencana peletakan bangunan/ kavling dengan segala unsur penun-jang dan batas lahan tertentu.

Berdasarkan PERMENPUPR RI No. 05/PRT/ M/2016 tentang Izin Mendirikan Bangunan, definisi dari Koefisisen Dasar Bangunan (KDB) adalah angka prosentase antara luas lantai dasar bangunan dan luas daerah perencanaan. Koefisisen Lantai Bangunan (KLB) adalah angka prosentase antara luas seluruh lantai bangunan dan luas daerah perencanaan. Koefisisen Dasar Hijau $(\mathrm{KDH})$ adalah angka prosentase antara luas ruang terbuka diluar bangunan yang digunakan untuk taman/penghijauan dan luas daerah perencanaan.

PERDA Kota Batu Nomor 7 tahun 2011 tentang RTRW Kota Batu Tahun 2010 - 2030 Bab VII tabel 7.1 No. 2 
menetapkan bahwa: Ketentuan intensitas pemanfaatan lahan per kavling, yaitu:

- $\quad$ Tipe kecil: KDB : 70\%, KLB : 0,6 - 0,7, Tinggi lantai bangunan: 1, GSB: $2-3 \mathrm{~m}$

- $\quad$ Tipe sedang KDB: $60 \%$, KLB: 0,5 - 1,2, Tinggi lantai bangunan: 1-2, GSB: $3 \mathrm{~m}$

- $\quad$ Tipe besar: KDB: 40\%, KLB: 0,4 - 1,5, Tinggi lantai bangunan: $1-2$, GSB: $5 \mathrm{~m}$

Pada Peraturan Menteri No. 11/PERMEN/ M/2008, klasifikasi lingkungan perumahan dan pemukiman berdasarkan kepadatan hunian dibedakan menjadi rumah susun dan rumah tidak bersusun. Syarat rumah tidak bersusun nilai dari KLB harus $<1$.

Berdasarkan Rencana Tata Ruang Wilayah Kota Batu 2010 - 2030 Bab IV, rumah dikategorikan menjadi 3 yaitu rumah besar (luasan lantai diatas $500 \mathrm{~m}^{2}$ ), rumah sedang (luasan lantai $120-500 \mathrm{~m}^{2}$ ), dan rumah kecil (luasan lantai $\left.<120 \mathrm{~m}^{2}\right)$.

Hunian berimbang merupakan rasio perbanding-an pada suatu perumahan berbentuk rumah deret yang terdiri dari rumah tipe sederhana (kecil), tipe menengah (sedang), dan tipe mewah (besar). Penggolongan tipe rumah dapat dianalisis dengan menggunakan perhitung-an luas lantai. Dalam RTRW Kota Batu Tahun 2010 - 2030 Bab VII tabel 7.1 No. 2 dinyatakan bahwa komposisi kawasan perumahan adalah 1 rumah mewah, 3 rumah menengah, dan 6 rumah sederhana atau rasio hunian berimbang pada suatu perumahan adalah $1: 3: 6$.

Pada PERMENPERA Nomor 11 tahun 2008 tentang Pedoman Keserasian Kawasan Perumah-an dan Pemukiman mengatur komposisi lahan efektif dan lahan non efektif, yaitu

Ketentuan Luas Lahan Efektif: Luas daerah perencanaan $>100$ ha, luas lahan efektif $\leq 55 \%$.

- Ketentuan Luas Prasarana dan Utilitas: Luas daerah perencanaan $>100$ ha, luas lahan prasarana $\&$ utilitas $\leq$ $30 \%$.

- Ketentuan Luas Sarana: Luas daerah perencanaan > 100

ha, luas lahan sarana paling kecil 15\%.

Giatman (2011) menjelaskan bahwa cash flow adalah aliran uang masuk dan keluar tiap periode waktu pada suatu perusahaan. Cash flow terdiri dari Cash in (pendapatan/manfaat, dan Cash out (biaya-biaya yang dikeluarkan).

Pemahaman Soeharto (2002) mengenai jumlah uang saat ini akan bernilai tinggi diwaktu yang akan datang adalah konsep dasar dalam berinvestasi. Masalah finansial berupa arus kas investasi mencakup periode waktu yang cukup lama sehingga perlu diperhitungkan pengaruh waktu terhadap nilai uang yang dirumuskan sebagai bunga (interest).

Menururt SeanRoss (2018), jika menggunakan modal sendiri dan modal pinjaman maka digunakan WACC sebagai bunga diskonto. Perhitungan WACC menggunakan rumus 1 :

$$
\begin{aligned}
& \text { WACC }=\text { Wh } . \mathrm{Kh}+\mathrm{We} \cdot \mathrm{Ke} \\
& \begin{aligned}
\mathrm{Kh} \quad & \mathrm{Rh}(1-\mathrm{t})=0,1162(1-0,3) \\
& =0,0814 \text { atau } 8,14 \%
\end{aligned}
\end{aligned}
$$

Keterangan: $\mathrm{Kh}=$ biaya modal berasal dari hutang setelah pajak (\%); Rh = Suku bunga hutang (missal 11,62\%); $\mathrm{t}=$ pajak $(\%)$; dan Ke dihitung dengan rumus 2 .

$$
\mathrm{Ke}=\mathrm{Rf}+\mathrm{Be}(\mathrm{Rm}-\mathrm{Rf})
$$

Keterangan: $\mathrm{Ke}=$ biaya modal ekuitas; $\mathrm{Rf}=$ tingkat keuntungan bebas resiko; $\mathrm{Be}=$ faktor yang menun-jukkan sensitifitas saham terhadap pasar modal (beta saham); $\mathrm{Rm}=$ tingkat keuntungan pasar modal.

Menurut Giatman (2011) analisis $P P$ bertujuan untuk mengetahui periode investasi akan dapat kembali saat kondisi Break Event Point. Perhitungan PP untuk arus kas tahunan yang jumlahnya berubah-ubah digunakan rumus 3 .

$$
k=(n-1)+\left[C_{f}-\sum_{1}^{n-1} A_{n}\right]\left(\frac{1}{A_{n}}\right)
$$

Keterangan: $\mathrm{C}_{\mathrm{f}}=$ Biaya Pertama, $\mathrm{An}=$ Arus kas tahun $\mathrm{n}$, dan $\mathrm{n}=$ tahun pengembalian ditambah 1 .

NPV merupakan metode menghitung nilai bersih pada waktu sekarang (present). Perhitungan NPV menggunakan rumus 4 .

$N P V=\sum_{t=0}^{n} \frac{(C) t}{(1+i) t}-\sum_{t=0}^{n} \frac{(C o) t}{(1+i)^{t}}$

Keterangan: $\mathrm{n}=$ Umur unit usaha hasil investasi; $(\mathrm{C}) \mathrm{t}=$ Arus kas masuk tahun ke-t; $\mathrm{i}=$ Arus pengembalian (rate of return $) ;(\mathrm{Co}) \mathrm{t}=$ Arus kas keluar tahun ke-t; dan $\mathrm{t}=$ Waktu.

Kriteria keputusan untuk mengetahui apakah rencana investasi layak atau tidak yaitu:

- $\quad$ NPV $>0$, investasi menguntungkan.

NPV $<0$, investasi merugikan (unfeasible).

$\mathrm{NPV}=0$, investasi dikatakan layak (feasible).

Sedangkan metode $B C R$ digunakan sebagai analisis tambahan untuk memvalidasi hasil evaluasi yang dilakukan oleh metode lain. Metode ini sangat baik dilakukan dalam rangka mengevaluasi proyek-proyek pemerintah yang berdampak langsung pada masyarakat. Metode ini menekankan pada perbandingan aspek manfaat yang diperoleh dengan biaya yang harus ditanggung. Nilai BCR dapat dihitung dengan menggunakan rumus 5 .

$B C R=\frac{\text { Nilai sekarang benefit }}{\text { Nilai sekarang biaya }}=\frac{(P V) B}{(P V) C}$

Keterangan : $(\mathrm{PV}) \mathrm{B}=$ Nilai sekarang benefit, dan $(\mathrm{PV}) \mathrm{C}=$ Nilai sekarang biaya. Kriteria keputusan untuk mengetahui apakah rencana investasi layak atau tidak yaitu:

- $\quad$ BCR $>1$, investasi dikatakan menguntungkan

- $\quad \mathrm{BCR}<1$, investasi merugikan (unfeasible)

- $\quad \mathrm{BCR}=1$, investasi dikatakan layak (feasible)

Soeharto (2002) mengatakan bahwa analisis rencana proyek menarik jika dilihat dari segi pengembalian yang telah ditentukan. Pada metode ini kajian yang digunakan yaitu dengan tingkat pengembalian dimana Net Present Value sama dengan nol. Nilai IRR yang diperoleh akan diukur berdasarkan MARR (Minimum Attractive Rate Of Return) atau tingkat pengembalian suku bunga yang diinginkan. Perhitungan Internal Rate of Return menggunakan rumus 6, dengan cara memasukkan nilai i coba-coba, sampai diperoleh $\mathrm{NPV}=0$.

$$
\sum_{t=0}^{n} \frac{(C) t}{(1+i) t}-\sum_{t=0}^{n} \frac{(C o) t}{(1+i)^{t}}=0
$$

Keterangan:

$(\mathrm{C}) \mathrm{t}=$ Arus kas masuk tahun ke-t; $\mathrm{i}=$ Tingkat pengembalian (diskonto); $(\mathrm{Co}) \mathrm{t}=$ Arus kas keluar tahun ke-t; 
$\mathrm{n}=$ Tahun

Kriteria usulan investasi dengan parameter IRR yaitu:

- $\quad$ IRR $>$ MARR, nvestasi menguntungkan

- $\quad$ IRR $<$ MARR, investasi merugikan

- $\quad$ IRR = MARR, investasi dikatakan layak

\section{METODE}

Objek penelitian adalah Proyek Pembangunan Perumahan X di Kota Batu. Data penelitian merupakan data sekunder tentang Gambar Rumah, Site Plan eksisting, AHSP Kota Batu, volume pekerjaan, biaya tanah dan perijinan. Variabel yang akan diteliti meliputi Site Layout kondisi eksisting, alternative site lay out yang akan ditawarkan, dan parameter kelayakan finansial proyek.

Diagram alir penelitian disajikan pada Gambar 1. Tahapan penelitian ini meliputi:

- Mengumpulkan data penelitian

- Menganalisis site layout perumahan kondisi eksisting.

- Membuat alternatif site layout perumahan

- Menghitung biaya investasi

- Menghitung parameter kelayakan finansial proyek

- Menentukan site layout yang terbaik dari site layout yang ditinjau berdasarkan nilai parameter kelayakan finaansial.

- Menentukan keputusan terbaik

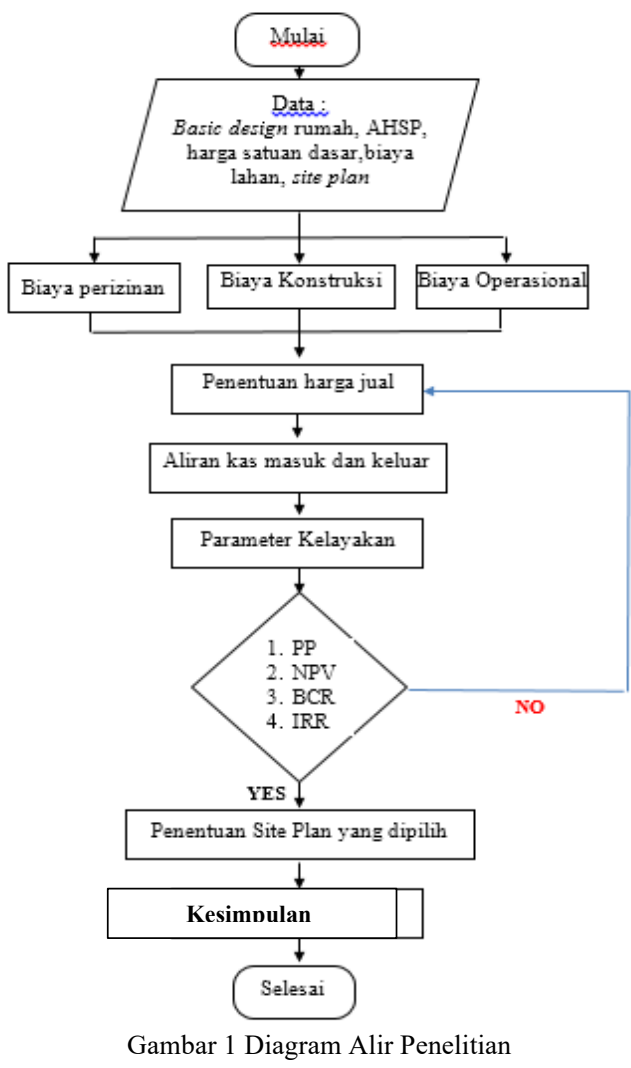

\section{A. Hasil dan Manfaat}

\section{Analisis Site plan}

Analisis Site plan kondisi eksisting Perumahan $\mathrm{X}$ ini meliputi: analisis luasan bangunan, $\mathrm{KDB}, \mathrm{KLB}, \mathrm{KDH}$, lokasi perumahan, pemanfaatan lahan, dan konsep hunian berimbang. Gambar site plan eksisting dapat dilihat pada gambar 2 .

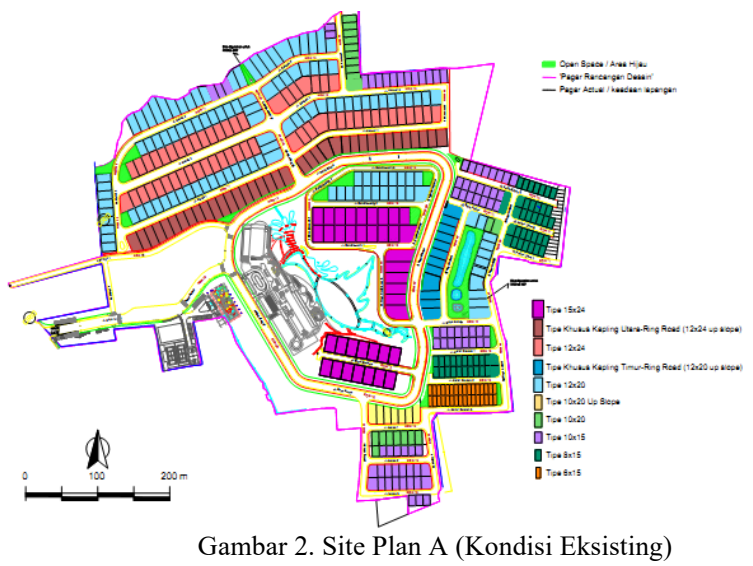

Perumahan $\mathrm{X}$ ini dibangun diatas lahan seluas $267.303,9 \mathrm{~m} 2$. Rumah yang dibangun terdiri dari 10 tipe dan tergolong 1 tipe kecil dan 9 tipe menengah. Masing-masing tipe dapat dihitung luas bangunannya yang terdiri dari bangunan 2 lantai, dan ada tipe rumah yang ada bassmentnya. Luasan bangunan digunakan untuk menghitung. KDB, KLB, dan $\mathrm{KDH}$ per kavling, hasil perhitungan disajikan dalam Tabel 1.

Tabel 1. Hasil Analisis KLB, KDB, dan KDH

\begin{tabular}{|c|c|c|c|c|c|}
\hline No. & Tipe & $\begin{array}{c}\text { Luas } \\
\text { Bangunan } \\
(\mathrm{m} 2)\end{array}$ & KDB & $\begin{array}{c}\text { KL } \\
\text { B }\end{array}$ & KDH \\
\hline 1 & $6 \times 15$ & 93,475 & $47,5 \%$ & 1,04 & $35,0 \%$ \\
\hline 2 & $8 \times 15$ & 121,290 & $48,3 \%$ & 1,01 & $38,5 \%$ \\
\hline 3 & $10 \times 15$ & 145,595 & $53,3 \%$ & 0,97 & $35,3 \%$ \\
\hline 4 & $10 \times 20$ & 167,267 & $44,3 \%$ & 0,84 & $37,7 \%$ \\
\hline 5 & $12 \times 20$ & 167,267 & $36,9 \%$ & 0,70 & $54,8 \%$ \\
\hline 6 & $12 \times 24$ & 192,583 & $33,6 \%$ & 0,67 & $53,4 \%$ \\
\hline 7 & $15 \times 24$ & 256,785 & $32,5 \%$ & 0,71 & $61,8 \%$ \\
\hline 8 & $\begin{array}{l}10 \times 20 \\
\text { upslope }\end{array}$ & 288,168 & $40,8 \%$ & 1,44 & $18,4 \%$ \\
\hline 9 & $\begin{array}{l}12 \times 20 \\
\text { upslope }\end{array}$ & 298,694 & $37,3 \%$ & 1,24 & $21,0 \%$ \\
\hline 10 & $\begin{array}{l}12 \times 24 \\
\text { upslope }\end{array}$ & 298,694 & $31,0 \%$ & 1,04 & $23,3 \%$ \\
\hline
\end{tabular}

Berdasarkan Tabel 1 diketahui bahwa ada beberapa tipe rumah yang belum memenuhi syarat KDB karena KDB $<70 \%$ (rumah sederhana) $<60 \%$ (rumah menengah). Rumah yang sesuai dengan ketentuan KLB ada 7 tipe rumah dan 3 tipe rumah tidak sesuai (tipe $6 \times 15$, tipe $10 \times 20$ upslope dan tipe 12 x 20 upslope). Syarat KLB untuk rumah menengah memiliki KLB 0,5 - 1,2, dan rumah sederhana memiliki KLB $0,6-0,7$.

Berdasarkan hasil analisis site plan eksisting diketahui: Lokasi perumahan berada di salah satu daerah pengembangan kawasan Pemerintah Kota Batu untuk perumahan seluas 2.104 ha, dengan kepadatan sedang. Jumlah rumah berdasarkan kategori tipe rumah yaitu sebanyak 1 tipe rumah sederhana, dan 9 tipe menengah, hal ini menunjukkan bahwa perumahan ini belum memenuhi rasio hunian berimbang. Lahan efektif Site Plan A seluas $100.104 \mathrm{~m} 2$, Luas prasarana yaitu $68.812,711 \mathrm{~m} 2$, dan luas sarana yaitu 98.387,189 m2. Dan dapat ditentukan prosentase lahan efektif yaitu sebesar 37,45\% $<60 \%$ (sesuai), prosentase luas prasarana yaitu $25,743 \%<30 \%$ (sesuai) dan prosentase 
luas sarana yaitu 36,807\% > 10\% (sesuai). Dengan jumlah rumah 463 unit, maka dapat ditentukan kepadatan hunian site plan A yaitu 46 unit/ha $<125$ unit/ha. Jika jumlah penghuni rumah rata-rata 5 jiwa, maka tingkat kepadatan hunian: 230 jiwa/ha. Prosentase luas RTH (Ruang Terbuka Hijau) $31,013 \%$ dengan rincian luas RTH privat: $41.174,25 \mathrm{~m}^{2}$; luas RTH public: $41.724,24 \mathrm{~m}^{2}$. Penyesuaian rumah dengan koridor jalan ditinjau mengenai Garis Sempadan Bangunan (GSB), dengan jarak rumah ke pagar : $5 \mathrm{~m}$ dan jarak pagar ke tepi jalan: $2 \mathrm{~m}$, diperoleh GSB: $7 \mathrm{~m}>3 \mathrm{~m}$ (syarat).

Perencanaan Site Plan B, dan Site Plan C
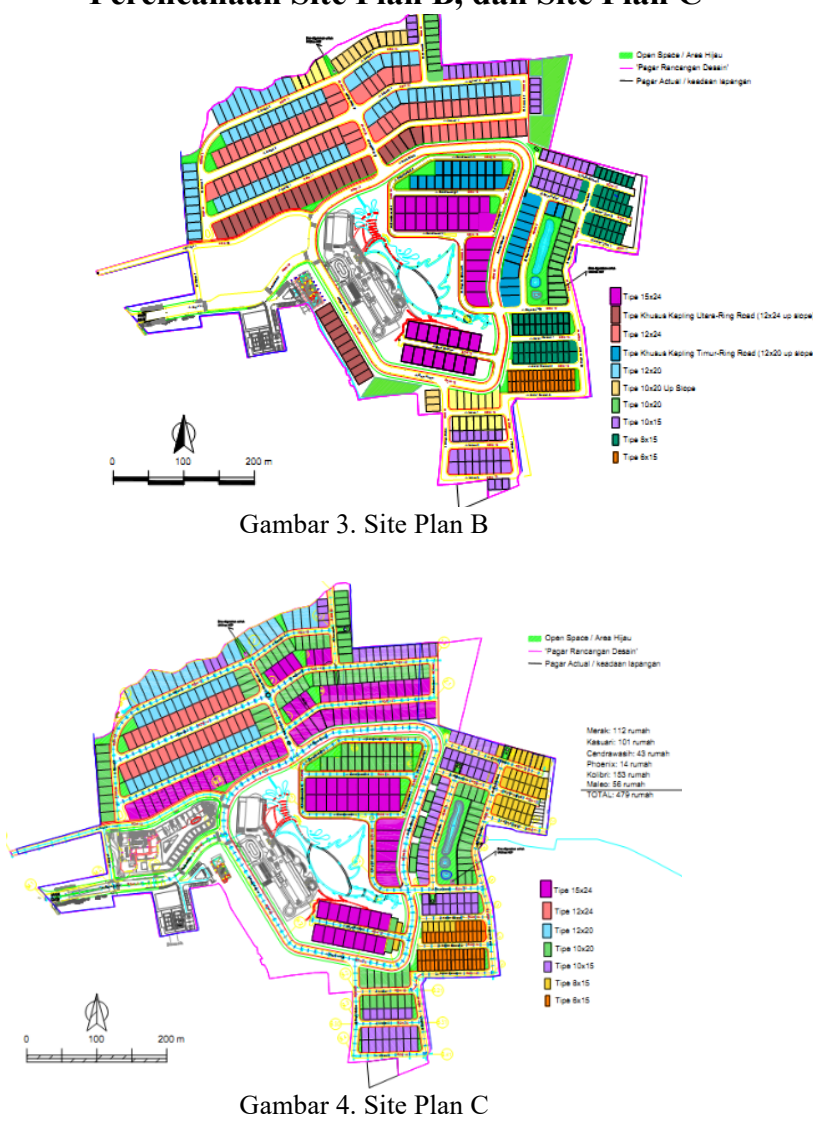

Tabel 2 Luas Lahan Efektif Site Plan $B \& C$

\begin{tabular}{|c|c|c|c|c|c|c|c|}
\hline \multirow[b]{2}{*}{ No } & \multirow[b]{2}{*}{ Tipe } & \multicolumn{3}{|c|}{ SITE PLAN B } & \multicolumn{3}{|c|}{ SITE PLAN C } \\
\hline & & $\begin{array}{c}\text { Jml. } \\
\text { Ru- } \\
\text { mah } \\
\text { (unit) }\end{array}$ & $\begin{array}{c}\text { Luas } \\
\text { Kav- } \\
\text { ling } \\
\left(\mathrm{m}^{2}\right)\end{array}$ & $\begin{array}{l}\text { Total } \\
\text { Luas } \\
\left(\mathbf{m}^{2}\right)\end{array}$ & $\begin{array}{l}\text { Jml. } \\
\text { Ru- } \\
\text { mah } \\
\text { (unit }\end{array}$ & $\begin{array}{l}\text { Kav- } \\
\text { ling } \\
\left(\mathrm{m}^{2}\right)\end{array}$ & $\begin{array}{c}\text { Total } \\
\text { Luas } \\
\left(\mathbf{m}^{2}\right)\end{array}$ \\
\hline 1 & $6 \times 15$ & 32 & 90 & 2.880 & 53 & 90 & 4.770 \\
\hline 2 & $8 \times 15$ & 78 & 120 & 9.360 & 48 & 120 & 5.760 \\
\hline 3 & $10 \times 15$ & 69 & 150 & 10.350 & 102 & 150 & 15.300 \\
\hline 4 & $10 \times 20$ & 24 & 200 & 4.800 & 121 & 200 & 24.200 \\
\hline 5 & $12 \times 20$ & 75 & 240 & 18.000 & 34 & 240 & 8.160 \\
\hline 6 & $12 \times 24$ & 74 & 288 & 21.312 & 24 & 288 & 6.912 \\
\hline 7 & $15 \times 24$ & 38 & 360 & 13.680 & 97 & 360 & 34.920 \\
\hline 8 & $\begin{array}{l}10 \times 20 \\
\text { upslope }\end{array}$ & 33 & 200 & 6.600 & & & \\
\hline 9 & $\begin{array}{l}12 \times 20 \\
\text { upslope }\end{array}$ & 33 & 240 & 7.920 & & & \\
\hline 10 & $\begin{array}{l}12 \times 24 \\
\text { upslope }\end{array}$ & 35 & 288 & 10.080 & & & \\
\hline \multicolumn{2}{|c|}{ TOTAL } & 491 & 2.176 & 104.982 & 479 & 1.448 & 100.022 \\
\hline
\end{tabular}

Berdasarkan hasil analisis diketahui bahwa site Plan A sudah cukup memenuhi persyaratan yang berlaku. Oleh karena itu perencanaan site plan $\mathrm{B}$ dan $\mathrm{C}$ mengacu pada site plan A tetapi ada perbedaan yaitu pada jumlah rumah dan
RTH. Hasil perencanaan site plan B dan C disajikan pada gambar 3 dan gambar 4. Perhitungan Luas lahan efektif disajikan pada tabel 2. Prosentase lahan efektif site plan $B$ : $39,27 \%$

Prosentase lahan efektif site plan C: 37,41\%. Luas prsarana Site plan B dan C sama dengan site plan A yaitu $68.812,711 \mathrm{~m}^{2}$, dan dapat diperoleh prosentase luas sarana site plan $B=34,98 \%$, dan site plan $C=36,84 \%$. Kepadatan hunian site plan B dan C masing-masing 235 jiwa/ha dan 240 jiwa/ha (sesuai syarat). Prosentase RTH site plan B dan C yaitu $32,741 \%$ dan $33,46 \%$.

\section{B. Analisis Kelayakan Finansial}

\section{Analisis Cash Flow Proyek}

Arus kas investasi pada proyek pembangun-an Perumahan $\mathrm{X}$ meliputi seluruh pendapatan maupun pengeluaran. Beberapa hal yang harus dipertimbang-kan dalam analisis arus kas dalam investasi ini yaitu: Periode investasi: 6 tahun; Sumber Modal 50\% modal sendiri dan $50 \%$ modal pinjaman; Suku bunga pinjaman sebesar 11,62\%, dan Suku bunga modal sendiri sebesar 6,569\% (Sumber: Pusat Informasi Pasar Uang (PIPU) Bank Indonesia); Ratarata BI rate selama 10 tahun terakhir yaitu 6,26\% (Sumber: Bank Indonesia); Biaya konstruksi naik setiap tahun 5,01\%; Besarnya tanda jadi pembelian rumah sebesar 2\%; dan Menurut Atmawati (2015), pembayaran rumah oleh pembeli sebesar $40 \%$ untuk membangun rumah dan akan dicairkan lagi setelah kemajuan pembangunan; $\mathrm{PPn} 10 \%$ dan $\mathrm{PPh} 2,5 \%$ jumlah bruto

Jika Modal investasi berasal dari modal sendiri dan pinjaman maka digunakan WACC sebagai bunga diskonto. Perhitungan WACC menggunakan rumus 1, dan diperoleh WACC $=8,64 \%$, dengan ketentuan lainnya sebagai berikut: Nilai beta saham sebesar 1,092 diperoleh dari nilai rata-rata dari nilai beta saham 16 perusahaan (Pefindo Beta Stock). Dan nilai risk free sebesar $4,53 \%$ diperoleh dari nilai rata selama 12 bulan dari tahun 2017 - 2018 (Bank Indonesia). Retun market ( $\mathrm{Rm}$ ) didapatkan dari data IHSG (Indeks Harga Saham Gabungan) 10 tahun terakhir sebesar 8,75\%. Dengan demikian nilai $\mathrm{Ke}$ dapat dihitung dan diperoleh $\mathrm{Ke}=0,0914$ sehingga $\mathrm{WACC}=8,64 \%$ > rata-rata $\mathrm{BI}$ rate sebesar $6,26 \%$, sehingga suku bunga per tahun harga jual rumah menggunakan WACC.

Biaya rumah terdiri dari biaya konstruksi, biaya tanah dan perijinan, biaya sarana prasarana, dan biaya operasional. Sedangkan harga jual rumah adalah biaya rumah ditambah keuntungan 25\% Rekan (2017). Hasil perhitungan disajikan pada tabel 3 .

Target penjualan rumah disajikan pada Tabel 4 . Pendapatan diperoleh dari sumber modal, penjualan rumah dan tanda jadi pemesanan (2\%). Pendapatan penjualan rumah terdiri dari pembayaran pertama sebesar $40 \%$ termasuk DP $(15 \%)$, dan biaya pelunasan rumah $(60 \%)$ dilakukan setelah terjadi kemajuan pembangunan (Atmawati, 2015) yag dalam hal ini dilakukan 1 tahun setelah tanda jadi

Tabel 3 Biaya Rumah dan Harga Jual Rumah

\begin{tabular}{llll}
\hline No. & Tipe Rumah & Biaya Rumah (Rp) & $\begin{array}{l}\text { Harga Jual Rumah } \\
(\mathrm{Rp})\end{array}$ \\
\hline Site plan A & & \\
1 & $6 \times 15$ & $804.950 .682,67$ & 1.006 .188 .353 \\
2 & $8 \times 15$ & $1.014 .575 .236,20$ & 1.268 .219 .045 \\
3 & $10 \times 15$ & $1.231 .094 .428,91$ & 1.538 .868 .036
\end{tabular}


Jurnal Teknik: Ilmu dan Aplikasi Vol. 09 No. 2, Juli 2020

\begin{tabular}{|c|c|c|c|}
\hline 4 & $10 \times 20$ & $1.469 .465 .623,57$ & 1.836 .832 .029 \\
\hline 5 & $12 \times 20$ & $1.660 .017 .672,41$ & 2.075 .022 .091 \\
\hline 6 & $12 \times 24$ & $2.012 .010 .545,31$ & 2.515 .013 .182 \\
\hline 7 & $15 \times 24$ & $2.507 .375 .889,93$ & 3.134 .219 .862 \\
\hline 8 & $\begin{array}{l}10 \times 20 \\
\text { upslope }\end{array}$ & $2.004 .505 .128,11$ & 2.505 .631 .410 \\
\hline 9 & $\begin{array}{l}12 \times 20 \\
\text { upslope }\end{array}$ & $1.947 .412 .672,68$ & 2.434 .265 .841 \\
\hline 10 & $\begin{array}{l}12 \times 24 \\
\text { upslope }\end{array}$ & $2.205 .234 .717,58$ & 2.756.543.397 \\
\hline \multicolumn{4}{|c|}{ Site plan B } \\
\hline 1 & $6 \times 15$ & $791.881 .026,54$ & $989.851 .283,17$ \\
\hline 2 & $8 \times 15$ & $997.149 .027,48$ & $1.246 .436 .284,35$ \\
\hline 3 & $10 \times 15$ & $1.209 .311 .668,01$ & $1.511 .639 .585,01$ \\
\hline 4 & $10 \times 20$ & $1.440 .421 .942,38$ & $1.800 .527 .427,98$ \\
\hline 5 & $12 \times 20$ & $1.625 .165 .254,98$ & $2.031 .456 .568,72$ \\
\hline 6 & $12 \times 24$ & $1.970 .187 .644,39$ & 2.462.734.555,49 \\
\hline 7 & $15 \times 24$ & 2.455.097.263,79 & $3.068 .871 .579,73$ \\
\hline 8 & $\begin{array}{l}10 \times 20 \\
\text { upslope }\end{array}$ & $1.975 .461 .446,92$ & 2.469.326.808,65 \\
\hline 9 & $\begin{array}{l}12 \times 20 \\
\text { upslope }\end{array}$ & $1.912 .560 .255,24$ & $2.390 .700 .319,05$ \\
\hline 10 & $\begin{array}{l}12 \times 24 \\
\text { upslope }\end{array}$ & $2.163 .411 .816,66$ & 2.704.264.770,83 \\
\hline \multicolumn{4}{|c|}{ Site plan C } \\
\hline 1 & $6 \times 15$ & $802.483 .972,57$ & $1.003 .104 .965,72$ \\
\hline 2 & $8 \times 15$ & $1.011 .286 .288,86$ & $1.264 .107 .861,08$ \\
\hline 3 & $10 \times 15$ & $1.226 .983 .244,74$ & $1.533 .729 .055,93$ \\
\hline 4 & $10 \times 20$ & $1.463 .984 .044,68$ & $1.829 .980 .055,86$ \\
\hline 5 & $12 \times 20$ & $1.653 .439 .777,75$ & $2.066 .799 .722,18$ \\
\hline 6 & $12 \times 24$ & $2.004 .117 .071,72$ & $2.505 .146 .339,65$ \\
\hline 7 & $15 \times 24$ & $2.497 .509 .047,94$ & $3.121 .886 .309,92$ \\
\hline
\end{tabular}

.Proyeksi pengeluaran pada perumahan ini terdiri dari biaya tanah, legalitas, konstruksi, operasional, dan pengembalian hutang. Pembelian tanah tahun 2017 sebesar Rp 227.208.315.000,00, biaya perijinan tahun 2017 untuk site plan A, B, dan C masing-masing Rp19.391.496.808,00, Rp 19.428.883.008,00, dan Rp 19.414.807.173,44, dan Biaya konstruksi rumah dikeluarkan bertahap sesuai target penjualan, dan Biaya operasional dikeluarkan mulai tahun 2017 - 2023 dan membutuhkan biaya sebesar Rp 5.606.900.000,00. Jumlah modal yang diperlukan ditentukan berdasarkan pengeluaran dan pendapatan pada tahun 2017 2019, karena cash flow tahun 2020 sudah positif.

Sumber modal terdiri dari 50\% modal sendiri dan 50\% modal pinjaman. Tingkat suku bunga pinjaman sebesar $11,62 \%$ dan suku bunga modal sendiri sebesar 6,56\%. Modal untuk Site Plan A, B, dan C dibulatkan sebesar Rp 267 Milyar. Modal pinjaman akan dikembalikan selama 5 tahun mulai 1 tahun setelah peminjaman (2018) dengan suku bunga flat setiap tahunnya.

\begin{tabular}{|c|c|c|c|c|c|c|c|}
\hline \multirow[b]{2}{*}{ No. } & \multirow{2}{*}{$\begin{array}{l}\text { Tipe } \\
\text { Rumah }\end{array}$} & \multirow{2}{*}{$\begin{array}{l}\text { Jumlah } \\
\text { Rumah } \\
\text { SPA }\end{array}$} & \multicolumn{5}{|c|}{ Target Penjualan SP A } \\
\hline & & & 1 & 2 & 3 & 4 & 5 \\
\hline 1 & $6 \times 15$ & 32 & 6 & 6 & 6 & 7 & 7 \\
\hline 2 & $8 \times 15$ & 58 & 12 & 12 & 12 & 11 & 11 \\
\hline 3 & $10 \times 15$ & 80 & 16 & 16 & 16 & 16 & 16 \\
\hline 4 & $10 \times 20$ & 20 & 4 & 4 & 4 & 4 & 4 \\
\hline 5 & $12 \times 20$ & 123 & 24 & 24 & 25 & 25 & 25 \\
\hline 6 & $12 \times 24$ & 56 & 12 & 11 & 11 & 11 & 11 \\
\hline 7 & $15 \times 24$ & 38 & 8 & 8 & 8 & 7 & 7 \\
\hline 8 & $\begin{array}{l}10 \times 20 \\
\text { upslope }\end{array}$ & 7 & 1 & 1 & 1 & 2 & 2 \\
\hline 9 & $\begin{array}{l}12 \times 20 \\
\text { upslope }\end{array}$ & 12 & 3 & 3 & 2 & 2 & 2 \\
\hline
\end{tabular}

\begin{tabular}{|c|c|c|c|c|c|c|c|}
\hline 10 & $\begin{array}{l}12 \times 24 \\
\text { upslope }\end{array}$ & 37 & 7 & 8 & 8 & 7 & 7 \\
\hline \multicolumn{2}{|c|}{ JUMLAH } & 491 & 99 & 98 & 98 & 98 & 98 \\
\hline & & SPB & & & & & \\
\hline 1 & $6 \times 15$ & 32 & 6 & 6 & 6 & 7 & 7 \\
\hline 2 & $8 \times 15$ & 78 & 16 & 16 & 16 & 15 & 15 \\
\hline 3 & $10 \times 15$ & 69 & 14 & 14 & 14 & 14 & 13 \\
\hline 4 & $10 \times 20$ & 24 & 5 & 5 & 5 & 4 & 5 \\
\hline 5 & $12 \times 20$ & 75 & 15 & 15 & 15 & 15 & 15 \\
\hline 6 & $12 \times 24$ & 74 & 14 & 15 & 15 & 15 & 15 \\
\hline 7 & $15 \times 24$ & 38 & 8 & 7 & 7 & 8 & 8 \\
\hline 8 & $\begin{array}{l}10 \times 20 \\
\text { upslope }\end{array}$ & 33 & 6 & 6 & 7 & 7 & 7 \\
\hline 9 & $\begin{array}{l}12 \times 20 \\
\text { upslope }\end{array}$ & 33 & 8 & 7 & 6 & 6 & 6 \\
\hline 10 & $\begin{array}{l}12 \times 24 \\
\text { upslope }\end{array}$ & 35 & 7 & 7 & 7 & 7 & 7 \\
\hline \multicolumn{2}{|c|}{ JUMLAH } & 491 & 99 & 98 & 98 & 98 & 98 \\
\hline & & SPC & & & & & \\
\hline 1 & $6 \times 15$ & 53 & 10 & 10 & 10 & 11 & 12 \\
\hline 2 & $8 \times 15$ & 48 & 9 & 9 & 10 & 10 & 10 \\
\hline 3 & $10 \times 15$ & 102 & 20 & 20 & 20 & 21 & 21 \\
\hline 4 & $10 \times 20$ & 121 & 24 & 24 & 24 & 24 & 21 \\
\hline 5 & $12 \times 20$ & 34 & 6 & 7 & 7 & 7 & 7 \\
\hline 6 & $12 \times 24$ & 24 & 4 & 5 & 5 & 5 & 5 \\
\hline 7 & $15 \times 24$ & 97 & 19 & 19 & 19 & 20 & 20 \\
\hline 8 & $\begin{array}{l}10 \times 20 \\
\text { upslope }\end{array}$ & & & & & & \\
\hline 9 & $\begin{array}{l}12 \times 20 \\
\text { upslope }\end{array}$ & & & & & & \\
\hline 10 & $\begin{array}{l}12 \times 24 \\
\text { upslope }\end{array}$ & & & & & & \\
\hline \multicolumn{2}{|c|}{ JUMLAH } & 479 & 92 & 94 & 95 & 98 & 96 \\
\hline
\end{tabular}

Berdasarkan ketentuan diatas maka arus kas keluar dan arus kas masuk dapat diperoleh. Hasil perhitungan kas bersih yang disajikan pada tabel 5 .

\begin{tabular}{crr}
\multicolumn{3}{c}{ Tabel 5 Proyeksi Net Cash } \\
\hline $\begin{array}{c}\text { Tahun } \\
\text { ke- }\end{array}$ & Net Cash (Rp) & Komulatif (Rp) \\
\hline SITE PLAN A & \\
0 & 18.290 .780 .493 & 18.290 .780 .493 \\
1 & -96.747 .057 .648 & -78.456 .277 .155 \\
2 & 3.927 .825 .928 & -74.528 .451 .227 \\
3 & 14.872 .795 .821 & -59.655 .655 .405 \\
4 & 22.375 .430 .404 & -37.280 .225 .001 \\
5 & 23.859 .098 .615 & -13.421 .126 .386 \\
6 & 135.842 .296 .182 & 122.421 .169 .796 \\
\hline
\end{tabular}

\begin{tabular}{crr}
\multicolumn{4}{c}{ Tabel 5 Proyeksi Net Cash (Lanjutan) } \\
\hline $\begin{array}{c}\text { Tahun } \\
\text { ke- }\end{array}$ & Net Cash (Rp) & Komulatif (Rp) \\
\hline SITE PLAN B & \\
0 & 18.201 .435 .619 & 18.201 .435 .619 \\
1 & -96.999 .056 .434 & -78.797 .620 .815 \\
2 & 7.978 .054 .257 & -70.819 .566 .558 \\
3 & 18.219 .833 .465 & -52.599 .733 .094 \\
4 & 26.179 .019 .872 & -26.420 .713 .221 \\
5 & 31.516 .121 .221 & 5.095 .407 .999 \\
6 & 145.306 .735 .139 & 150.402 .143 .139 \\
SITE PLAN C & \\
0 & 18.267 .470 .127 & 18.267 .470 .127 \\
1 & -96.983 .016 .632 & -78.715 .546 .504 \\
2 & -1.261 .838 .084 & -79.977 .384 .589 \\
3 & 11.722 .285 .713 & -68.255 .098 .876
\end{tabular}




\begin{tabular}{lrr}
4 & 19.841 .018 .871 & -48.414 .080 .004 \\
5 & 27.392 .351 .906 & -21.021 .728 .098 \\
6 & 136.348 .842 .748 & 115.327 .114 .649 \\
\hline
\end{tabular}

\section{Analisis Parameter Kelayakan Finansial}

Setelah diketahui arus kas keluar dan arus kas masuk, selanjutnya dapat ditentukan present value dari masingmasing arus kas dengan suku bunga 8,64\% dan diperoleh hasil seperti pada Tabel 6. Selanjutnya dapat dihitung nilai parameter kelayakan finansial seperti PP, NPV, BCR, dan IRR dengan masing-masing mengguna-kan rumus 3 , rumus 4, rumus 5, dan rumus 6. Hasilnya disajikan pada Tabel 7. Berdasarkan Tabel 7 dapat disimpulkan bahwa site plan yang terbaik secara finansial adalah site plan B karena memiliki parameter finansial yang memenuhi kriteria penilaian dan memiliki nilai yang lebih baik dari site plan A dan C.

Tabel 6. Proyeksi Present Value Net Cash

\begin{tabular}{|c|c|c|c|}
\hline $\begin{array}{c}\text { Tahun } \\
\text { ke- }\end{array}$ & PV Masuk (Rp) & PV Keluar (Rp) & NPV (Rp) \\
\hline \multicolumn{3}{|c|}{ Site plan A } & 58.614 .912 .810 \\
\hline 0 & 267.000 .000 .000 & 248.709 .219 .507 & 18.290 .780 .493 \\
\hline 1 & 3.449 .627 .324 & 92.502 .515 .438 & $\begin{array}{c}- \\
89.052 .888 .115\end{array}$ \\
\hline 2 & 162.218 .132 .251 & 158.890 .213 .469 & 3.327 .918 .782 \\
\hline 3 & 162.416 .159 .317 & 150.817 .084 .626 & 11.599.074.691 \\
\hline 4 & 162.044 .641 .514 & 145.982 .170 .009 & 16.062 .471 .505 \\
\hline 5 & 158.954 .519 .550 & 143.189.110.352 & 15.765 .409 .198 \\
\hline 6 & 155.574 .201 .954 & 72.952 .055 .698 & 82.622 .146 .256 \\
\hline \multicolumn{3}{|c|}{ Site plan B } & 77.882 .006 .896 \\
\hline 0 & 267.000 .000 .000 & 248.798 .564 .381 & 18.201 .435 .619 \\
\hline 1 & 3.652 .801 .939 & 92.937 .647 .700 & $\begin{array}{c}- \\
89.284 .845 .761\end{array}$ \\
\hline 2 & 171.712 .595 .939 & 164.953 .050 .813 & 6.759 .545 .125 \\
\hline 3 & 169.174.920.884 & 154.965 .540 .768 & 14.209 .380 .116 \\
\hline 4 & 169.260 .164 .449 & 150.467 .240 .553 & 18.792 .923 .896 \\
\hline 5 & 170.122 .713 .232 & 149.297 .762 .743 & 20.824 .950 .489 \\
\hline 6 & 166.744 .454 .961 & 78.365 .837 .549 & 88.378 .617 .412 \\
\hline \multicolumn{4}{|c|}{ Tabel 6. Proyeksi Present Value Net Cash (Lanjutan) } \\
\hline \multicolumn{3}{|c|}{ Site Plan C } & 52.343 .746 .589 \\
\hline 0 & 267.000 .000 .000 & 248.732 .529 .873 & 18.267 .470 .127 \\
\hline 1 & 3.272 .079 .279 & 92.542 .160 .862 & -89.270 .081 .583 \\
\hline 2 & 153.948 .996 .512 & 155.018 .110 .759 & -1.069 .114 .247 \\
\hline 3 & 157.845 .928 .771 & 148.703 .890 .571 & 9.142 .038 .200 \\
\hline 4 & 159.021 .139 .917 & 144.778 .026 .177 & 14.243 .113 .741 \\
\hline 5 & 163.732 .989 .006 & 145.632 .907 .202 & 18.100 .081 .804 \\
\hline 6 & 156.530 .348 .490 & 73.600 .109 .942 & 82.930 .238 .548 \\
\hline
\end{tabular}

Tabel 7 Nilai Parameter Kelayakan Finansial

\begin{tabular}{ccccc}
\hline $\begin{array}{c}\text { Parameter } \\
\text { Kelayakan }\end{array}$ & $\begin{array}{c}\text { PP } \\
\text { (thn) }\end{array}$ & NPV (Rp) & BCR & $\begin{array}{c}\text { IRR } \\
\text { (\%) }\end{array}$ \\
\hline SITE PLAN A & 5,37 & 58.614 .912 .810 & 1,058 & 27,004 \\
SITE PLAN B & 5,22 & 77.882 .006 .896 & 1,075 & 32,801 \\
SITE PLAN C & 5,42 & 52.343 .746 .589 & 1,052 & 24,322 \\
Indikator & 6 & 0 & 1 & 30 \\
Site Plan & B & B & B & B \\
Terbaik & & & &
\end{tabular}

- Berdasarkan hasil analisis Site Plan kondisi eksisting (site plan A) pada Perumahan $\mathrm{X}$ dengan luas lahan 267.303,9 $\mathrm{m}^{2}$ dapat diketahui bahwa site plan A sudah cukup memenuhi persyaratan yang ditentukan yaitu terdiri dari 1 tipe rumah sederhana dan 9 tipe menengah. Dengan demikian perencanaan site plan B dan C mengikuti site plan A, bedanya terletak pada luas lahan efektif, jumlah rumah, dan luas lahan hijau. Luas lahan efektif site plan A, B, dan C masing-masing yaitu $100.104 \mathrm{~m}^{2}, 104.982 \mathrm{~m}^{2}$, dan $100.022 \mathrm{~m}^{2}$. Dan jumlah rumah pada site plan $\mathrm{A}, \mathrm{B}$, dan $\mathrm{C}$ masing-masing 463, 491, 479 unit.

Berdasarkan hasil analisis parameter kelayakan finansial terhadap semua site plan yang ditinjau yaitu site plan A, $\mathrm{B}$, dan $\mathrm{C}$ masing-msing diperoleh nilai Payback Period (PP) 5,37 tahun, 5,22 tahun, dan 5,42 tahun dan semua site plan dinyatakan layak; NPV sebesar Rp 58.614.912.810, Rp 77.882.006.896, dan Rp 52.343.746.589 dan semua site plan dinyatakan layak; BCR sebesar 1,058, 1,075, dan 1,052 dan semua site plan dinyatakan layak; dan nilai IRR sebesar 27,004\%, $32,801 \%$, dan $24,322 \%$ dan hanya site plan B yang dinyatakan layak.

- Berdasarkan hasil perbandingan nilai parameter kelayakan finansial terhadap semua site plan yang ditinjau dapat ditentukan site plan yang terbaik secara finansial yaitu site plan B.

\section{DAfTAR Pustaka}

[1] Giatman, M. 2011. Ekonomi Teknik. Jakarta: Raja Grafindo Persada.

[2] Laporan Inflasi (Indeks Harga Konsumen). 2018. Laporan Inflasi berdasarkan Perhitungan Inflasi Tahunan. Jakarta: Bank Indonesia

[3] Pefindo Beta Stock Edition: 29 December 2017. Jakarta: PT. Pemeringkat Efek Indonesia

[4] Peraturan Daerah Kota Batu Nomor 7 tahun 2011 tentang Rencana Tata Ruang Wilayah Kota Batu Tahun 2010-2030. Batu

[5] Peraturan Menteri Negara Perumahan Rakyat Nomor: 11/PERMEN/M/2008 tentang Pedoman Keserasian Kawasan Perumahan dan Pemukiman. Jakarta

[6] Peraturan Menteri Pekerjaan Umum dan Perumahan Rakyat Nomor: 38/PRT/M/2015 tentang Bantuan Prasarana, Sarana, dan Utilitas Umum untuk Perumahan Umum. Jakarta

[7] Peraturan Menteri Pekerjaan dan Perumahan Rakyat Republik Indonesia Nomor: 05/PRT/M/2016 tentang Izin Mendirikan Bangunan Gedung. Jakarta

[8] Pusat Informasi Pasar Uang (PIPU) Bank Indonesia. 2018. Suku Bunga Deposito. Jakarta: Bank Indonesia

[9] Ross, Sean. 2018. What is the difference between the cost of capital and the discount rate? Investopedia.com. Diakses pada 18 Juli 2018 pukul 22.50 WIB

[10] Soeharto, I. 2002. Studi Kelayakan Proyek Industri. Jakarta : Erlangga.

[11] Undang-Undang Republik Indonesia Nomor 1 tahun 2011 tentang Perumahan dan Kawasan Pemukiman. Jakarta

\section{KESIMPULAN}

Berdasarkan hasil dari analisis dan pembahasan, dapat disimpulkan sebagai berikut: 